\title{
海浜の粒径に着目した試験養浜効果の把握とその検証
}

\section{Evaluation and Verification of the Effect of An Examination of Beach Nourishment Focused on the Grain Size}

\author{
細井寛昭 ${ }^{1}$. 平野宜 ${ }^{2} \cdot$ 神保正暢 $^{3}$
}

\author{
Hiroaki HOSOI, Giichi HIRANO and Masanobu JINBO
}

\begin{abstract}
The effect of the beach nourishment on the Yamamoto coast which has been suffering from serious beach erosion was evaluated. From the fluorescent sand survey, even medium sand with diameter of about $0.3 \mathrm{~mm}$ passed over the headland in coming of significant waves higher than $2 \mathrm{~m}$. About $80 \%$ of sand particles moved out from the injection point within 1 year. According to the Bruun equation, the profile of this beach was identified as the concave and eroded type. Sediment survey showed that sand particles larger than $0.25 \mathrm{~mm}$ stayed in shallow area with depth less than $2 \mathrm{~m}$ and remained there for more than 1 year. In addition, Numerical model built to estimate the effectiveness of different grain size on beach nourishment demonstrated availability of gravels for effective nourishment.
\end{abstract}

\section{1. はじめに}

仙台湾南部海岸は，図-1の通り，宮城県と福島県の県 境から北側の宮城県沿岸部に位置し, 北向きの沿岸漂砂 が卓越した海岸となっている. 仙台湾南部海岸の南側に 位置する山元海岸では, 漁港や港湾の建設等によって南 の福島県側からの沿岸漂砂が激減し, 侵食により砂浜が 消失した状態であり，現時点でも侵食が継続している.

当海岸では, 北向きの沿岸漂砂が大きいため, 養浜の みの対策では投入土砂の流出が大きく効率的ではないた め, 建設中のへッドランドと養浜の併用による海岸保全 対策を計画している.

そこで, 本研究では, 試験的に養浜を行い, 並行して モニタリング調査を実施することにより, 試験養浜効果 について検証し, 今後の効率的, 効果的な養浜計画を策 定するための基礎デー夕を蓄積することを目的とする.

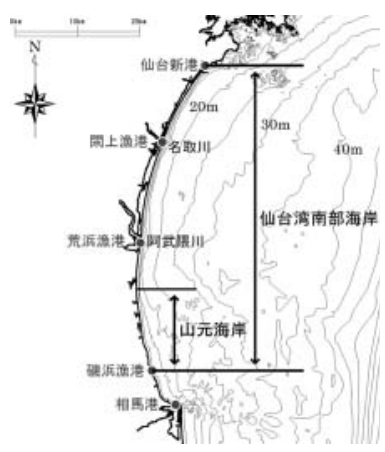

図-1 研究対象海岸位置

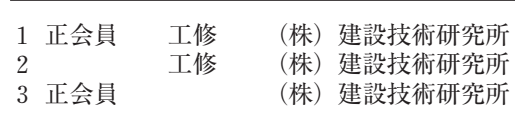

\section{2. 山元海岸の現状と試験養浜の実施}

山元海岸南端に位置するヘッドランドS2 号根元部に試 験養浜を実施した。試験養浜の概要および実施位置をそ れぞれ表-1, 図-2に示す。また, 試験養浜と並行して, 表-2に示すようなモニタリング調査を実施した.

表-1 試験養浜の概要

\begin{tabular}{l|l|l}
\hline 養浜材 & $\begin{array}{l}1.6 \text { 万 } \mathrm{m}^{3} \\
(\mathrm{~d} 50=0.28 \mathrm{~mm})\end{array}$ & $\begin{array}{l}\text { <内訳 }> \\
\text { 荒浜漁港南側のストック土砂 } \\
\left(1.3 \text { 万 } \mathrm{m}^{3} ; \mathrm{d} 50=0.29 \mathrm{~mm}\right) \\
\text { 磯浜漁港隣接海岸の堆積土砂 } \\
\left(0.3 万 \mathrm{~m}^{3} ; \mathrm{d} 50=0.18 \mathrm{~mm}\right)\end{array}$ \\
\hline 投入地 & $\mathrm{S} 2$ 号ヘッドランド南側 \\
\hline 投入時期 & 平成 19 年 11 月 3 日 $~ 12$ 月 1 日 \\
\hline
\end{tabular}

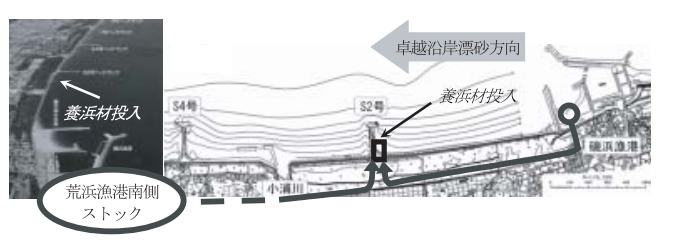

図-2 試験養浜実施箇所

表-2 観測項目及び目的

\begin{tabular}{|c|c|c|}
\hline 観測項目 & 内容抢よび目的 & 実施時期 \\
\hline 空中写真 & $\begin{array}{l}\text { 養浜実施前後の汀線変化 } \\
\text { 沈況を把握. }\end{array}$ & $\begin{array}{l}\text { 試験養浜実施前後 } \\
(\mathrm{H} 11.12 \sim \mathrm{H} 21.2)\end{array}$ \\
\hline 深浅測量 & $\begin{array}{l}\text { 海底の底質の変化状況を } \\
\text { 把握. }\end{array}$ & $\begin{array}{l}\text { 試験㝨浜実施前後 } \\
\text { 定期深浅測量 }\end{array}$ \\
\hline $\begin{array}{l}\text { 蛍光砂 } \\
\text { 調査 }\end{array}$ & $\begin{array}{l}\text { 蛍光塗料によって着色さ } \\
\text { れた土砂を投入し, 移動 } \\
\text { 状況を確認. }\end{array}$ & $\begin{array}{l}\text { 投入 : H20.11.12 } \\
\text { 採取 : } \\
\text { H20.11.18 (1週間後), } \\
\text { H20.12.11 (1ケ月後) }\end{array}$ \\
\hline 底質調査 & $\begin{array}{l}\text { 試験養浜実施前後の底質 } \\
\text { の変化を把握. }\end{array}$ & $\begin{array}{l}\text { 試験養浜実施前1回, } \\
\text { 実施後4回の計5回 }\end{array}$ \\
\hline $\begin{array}{c}\text { 堆砂高 } \\
\text { 調査 }\end{array}$ & $\begin{array}{l}\text { ヘッドランド静穏域の海 } \\
\text { 浜の変化状況を把握. }\end{array}$ & $\begin{array}{l}\text { 試験養浜実施前後 } \\
(\mathrm{H} 19.7 .9 \sim \mathrm{H} 21.2 .25)\end{array}$ \\
\hline
\end{tabular}




\section{3. 試験養浜の効果}

\section{（1）空中写真による汀線変化}

試験養浜実施箇所を上空から撮影した空中写真より, 砂浜が無かった $\mathrm{S} 2$ 号ヘッドランド南側に，試験養浜実施 1 週間後に三角状の砂浜が形成され，その後やや後退す るものの 1 年後も砂が保たれていることがわかる。これ は養浜による土砂投入とヘッドランドによる静穏効果に よるものといえる. 1 年後の写真からヘッドランド北側も 砂浜が見られるが，これも同様に養浜によるものである。

（2）波浪とヘッドランド基部砂浜の応答

試験養浜実施後 1 年間の $\mathrm{S} 2$ 号ヘッドランド根元部の堆 砂状況と波浪との応答について評価した。図-4に示すよ うに，S2 号ヘッドランド基部の根元部から沖側 $85 \mathrm{~m}$ 地点 の南側において, ヘッドランド天端から砂浜の堆砂点ま での距離を測り，標高（T.P.）に換算することによって 堆砂高を算定した。

試験養浜実施直前の 2007 年 10 月から試験養浜実施 1 年 後の 2008 年 12 月までの有義波高（相馬：ナウファス） および砂浜の堆砂高の経年変化を図-5に示す。
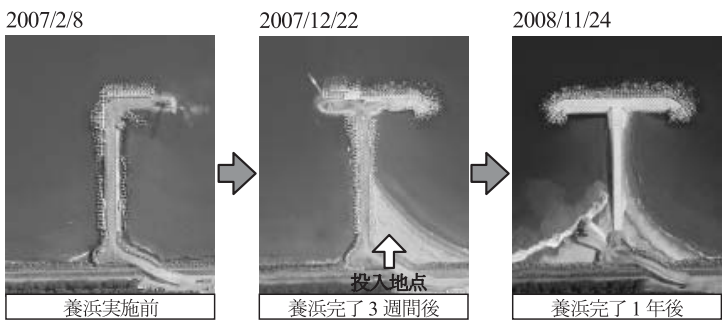

図-3 S2号ヘッドランド周辺の汀線変化状況

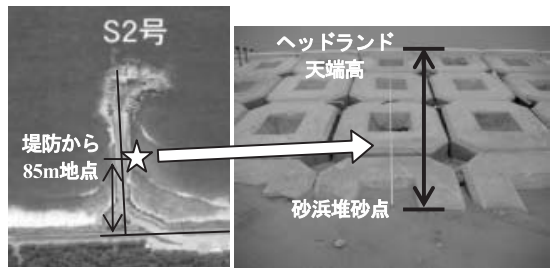

図-4 S2 号ヘッドランド基部の堆砂高調査地点
図より，3月〜4月にかけて 2〜 4mの高波浪が続いた 期間に堆砂高が急激に下がり，5月〜 10月に緩やかに上 昇していることが確認できる。これは，高波浪発生時に ヘッドランド基部付近の海浜が一時的に侵食し，大きな 波浪が発生していない夏季〜秋季にかけて徐々に砂が戻 ってきたためと推定できる.

\section{（3）深浅測量成果による地形変化状況の把握}

哚浅測量成果を踏まえ，試験養浜実施前（2007.9.20） ～実施完了4日後（2007.11.7）の地盤高変化の平面分布 を図-6に示す。また，養浜材を投入した S2 号ヘッドラン ド南側根元部の $100 \mathrm{~m}$ 四方の領域における，投入後の堆 積量変化を図-7に示す.

図-6より，試験養浜によって，S2号ヘッドランド根元 部で最大 $2 \mathrm{~m}$ 程度の堆積が見られる。一方で, 図-7より, 1.6 万 $\mathrm{m}^{3}$ の投入土砂量に対して，投入直後は 0.9 万 $\mathrm{m}^{3}$ ，投 入 1 年後は 0.3 万 $\mathrm{m}^{3}$ が残存し，ヘッドランド背後の 1 年後 の投入砂残存率は約 2 割という結果となった。つまり， ヘッドランドの漂砂制御効果がある程度発揮されたもの

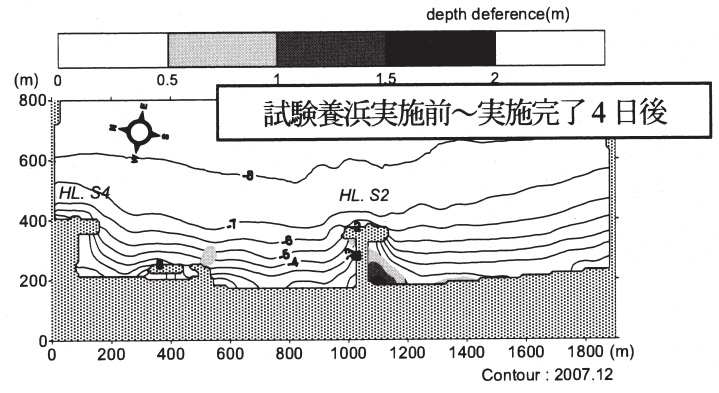

図-6 試験養浜実施前後の地盤高変化の平面分布

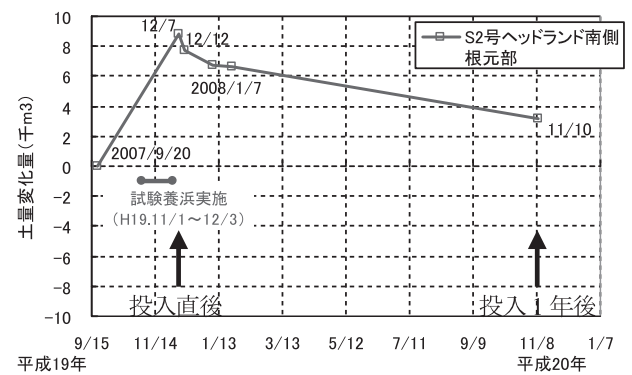

図-7 試験養浜実施箇所の堆積量変化

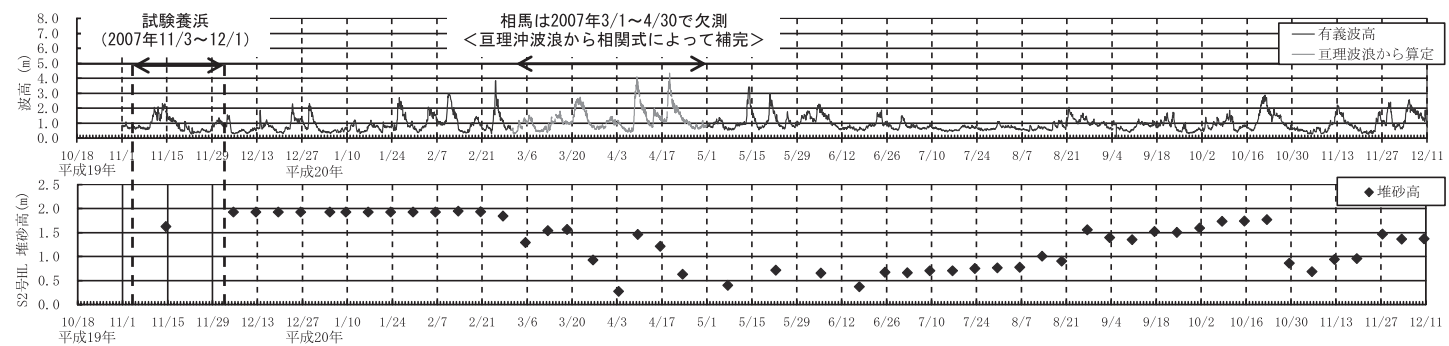

図-5 有義波高と S2 号ヘッドランド基部の堆砂高 
の，8割が流出するということが確認できた.

山元海岸の海浜特性については三浦ら（2008）が侵食 型の海岸と評価している. 養浜実施箇所付近における平 常時の波浪状況において, 砂村ら（1974）の式（1）によ って評価した結果，三浦らと同様，侵食型に該当した.

$$
\frac{H_{0}}{L_{0}}=C(\tan \beta)^{-0.27}\left(\frac{d}{L_{0}}\right)^{0.67}
$$

ただし，1991〜2004年の相馬波浪観測データより求 めたエネルギー平均波浪の $\mathrm{H}_{0}=1.2 \mathrm{~m}, \mathrm{~T}_{0}=8.5 \mathrm{~s}$, 海底勾配 $\tan \beta=0.02$, 中央粒径 $\mathrm{d}=0.2 \mathrm{~mm}$ として算定.

また, Bruun（1954）によって提案されている平衡海 浜断面を表す式（2）を用いて，侵食が顕著な S2 号へッ ドランド〜磯浜漁港間の中央部の平衡断面形状を求めて 現況断面と比較したものを図-8に示す．眓より，現況断 面は平衡断面に対して凹状で侵食型の状態であることが わかった。

$$
Z=A y^{2 / 3}
$$

$\mathrm{Z}$ : 水深, $\mathrm{y}$ : 汀線からの離岸距離, $\mathrm{A}$ ：底質粒径によ り決まる定数（ここでは，A=0.1）

\section{（4）蛍光砂調査成果による試験養浜の評価}

粒度の違いによって移動状況がどの程度異なるのかを 把握するために，粒径の異なる砂【細粒分；粒径 0.1 $0.3 \mathrm{~mm}$, 粗粒分; 粒径 $0.3 \sim 2 \mathrm{~mm}$ 以上】の蛍光砂を投入 し，その移動状況の調査を行った。このうち，投入 1 週 間後に採取した粗粒分の検出結果を波向頻度分布ととも に図-9に示す。

調査実施前は，ヘッド部先端が水深 $4 \mathrm{~m}$ に位置する $\mathrm{S} 2$ 号ヘッドランドを蛍光砂の粗粒分が越えることはほぼ無 いと想定していた。しかし，調査の結果，粗粒分がヘッ ドランドを越えて北側でも検出された。この投入時から 採取までの間に，最大有義波高 $2.2 \mathrm{~m}$ を観測していること から，0.3mm程度以上の砂でも，有義波高 $2 \mathrm{~m}$ 程度の波浪 来襲時はへッドランドを越えて移動することも留意する 必要があることが把握できた。

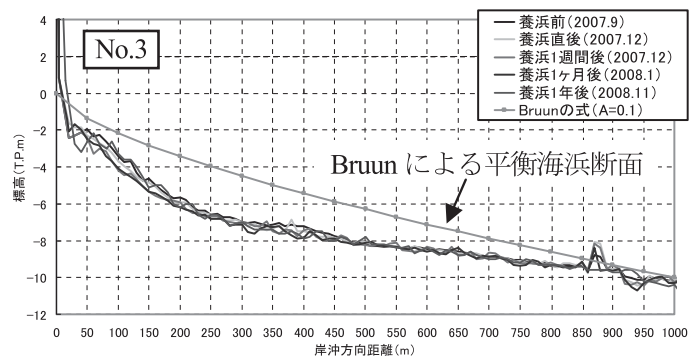

図-8 Bruunの平衡海浜断面と現地の断面形状の比較

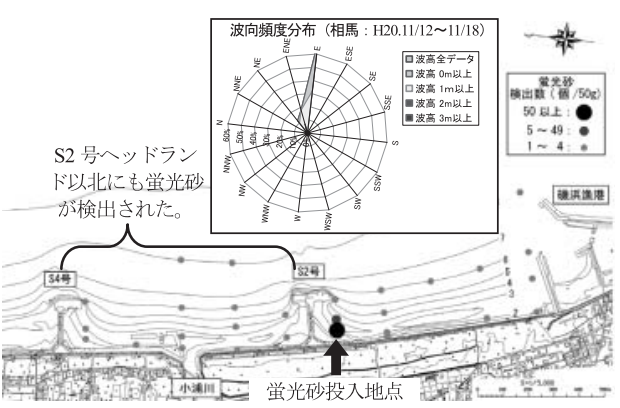

図-9 粗粒分の蛍光砂調査結果
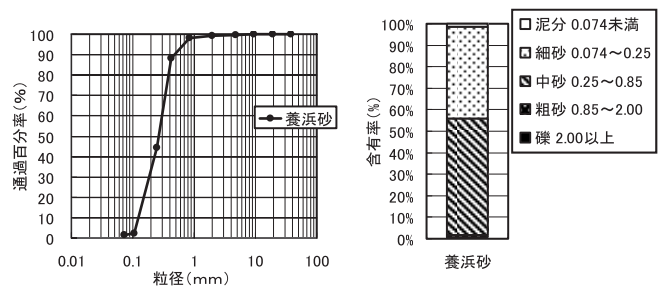

図-10 養浜砂の粒径加積曲線と粒径含有率

\section{（5）底質調査成果による試験養浜の評価}

試験養浜で投入した砂の粒径加積曲線および含有率を 図-10に示す。また，試験養浜実施前，実施1ケ月後およ び 1 年後の底質調査結果による中央粒径の平面分布およ びS2 号へッドランド南側の測線No. 2 とNo.5における水 深毎の粒径含有率をそれぞれ図-11，図-12に示す。

図-11の中央粒径の平面分布より，磯浜漁港〜小浦川 河口の間の汀線際の粒径が試験養浜実施前後で顕著に変 化しているのがわかる。一方で, 試験養浜実施 1 ケ月後 〜 年後は同場所で大きな変化は見られない. また, 水 深 $4 \mathrm{~m}$ 以深では全体的に変化が見られず，ほとんどが中 央粒径 $0.2 \mathrm{~mm}$ 未満となっている.

図-12 を見ると，試験養浜実施 1 ケ月後に，測線No.5で は中砂が増大し, 測線No.2では, 事前には見られなかっ た中砂や細砂がほとんどを占める結果となっている。つ まり，試験養浜の砂が多大に寄与していることがわかる. 両測線ともに 1 年後も 1 ケ月後の含有率とほぼ同様の結 果となっている.

以上を整理すると, 試験養浜実施後, 投入土砂の細 砂・中砂が汀線際に移動することにより，汀線際の主要 な粒度組成が「粗砂〜砂」から「細砂〜中砂」に変化し, その状態が 1 年後まで続いた。 また, 細砂〜中砂が $\mathrm{S} 2$ 号 ヘッドランドを越えて北側の汀線際にも移動しているこ とがわかった。これは前節で示した蛍光砂調査結果とも 一致している。一方で, 中砂以上の砂は, 水深 $4 \mathrm{~m}$ 以深 の粒度組成を変化させるほどは留まっていないことか ら，多くが汀線際に留まるものと推定される. 


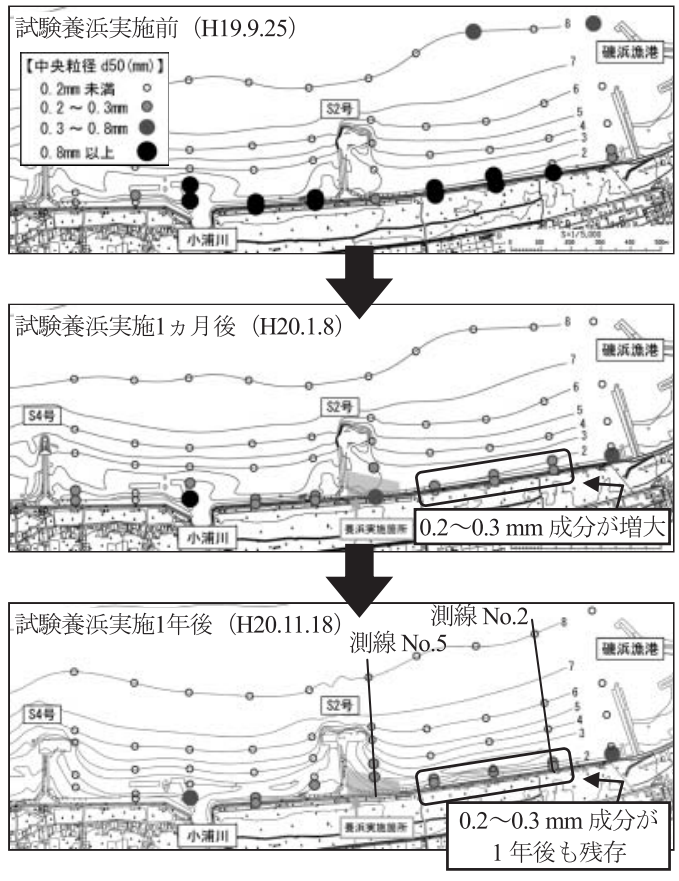

図-11 中央粒径の平面分布の変化

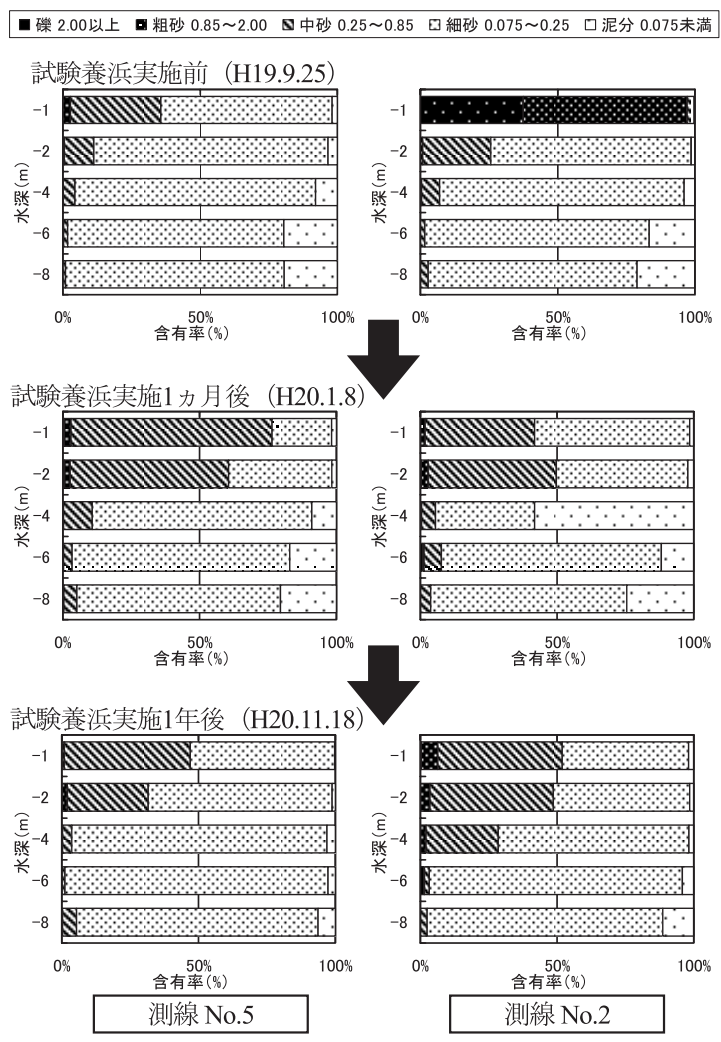

図-12 測線No.2, No.5の粒径含有率水深分布の変化

\section{4. 海浜変形モデルによる再現計算}

仙台湾南部海岸における養浜計画を策定するために, 熊田ら（2003）によって開発された，混合粒径を考慮し た等深線変化モデルを構築し, 山元海岸の地形変化の再 現計算を実施した。計算条件抒よび再現計算結果につい て以降に示す.

\section{（1）計算条件}

構築する海浜変形モデルの計算条件を表-3に示す.

\section{(2) 再現計算結果}

海浜変形モデルの再現性を評価するために，図-13に 示すエリア毎の土量変化の再現計算結果と実績值を比較 した．各エリアの1998～2008年の 11 年間の土量再現計 算結果を図-14に示し，そのうち，最も侵食が進行して いるエリア(5)の土量経年変化の比較を図-15に示す.

図-14より，各エリアで5万 $\mathrm{m}^{3}$ 程度の差はあるものの， 全体的な侵食の傾向は概ね再現できている。また，図-15 より，1998〜2003年で強い侵食傾向が見られ，その後， 概ね安定している傾向は良く再現できている。これは， 2003 年以降にエリア (5)に寄与する S2 号，S4号へッドラ

表-3 計算条件

\begin{tabular}{|c|c|c|}
\hline 計算対象範囲 & \multicolumn{2}{|c|}{ 山元海岸の磯浜漁港から北側約 $10 \mathrm{~km}$} \\
\hline 検証期間 & \multicolumn{2}{|c|}{$1998 （ \mathrm{H} 10 ） ２ 008 （ \mathrm{H} 20 ） （ 10$ 年間） } \\
\hline 波浪条件 & $\begin{array}{l}\text { 季別に卓越する3 } \\
\text { 方向の波高・波向 } \\
\text { を設定 }\end{array}$ & $\begin{array}{l}\text { 卓越波向毎の波高 } \\
\mathrm{ENE}: 1.24 \mathrm{~m} \\
\mathrm{E} \quad: 1.11 \mathrm{~m} \\
\mathrm{ESE}: 1.09 \mathrm{~m}\end{array}$ \\
\hline 粒度 & $\begin{array}{l}\text { 既往の底質調査成 } \\
\text { 果をもとに6粒径 } \\
\text { 成分で設定 }\end{array}$ & $\begin{array}{l}\text { 代表粒径 (平衡勾配) } \\
1: 0.09 \mathrm{~mm}(1 / 200) \\
2: 0.16 \mathrm{~mm}(1 / 40) \\
3: 0.33 \mathrm{~mm}(1 / 14) \\
4: 0.60 \mathrm{~mm}(1 / 9) \\
5: 1.3 \mathrm{~mm}(1 / 6) \\
6: 4.4 \mathrm{~mm}(1 / 4)\end{array}$ \\
\hline $\begin{array}{l}\text { 沿岸・岸沖漂 } \\
\text { 砂量係数 }\end{array}$ & \multicolumn{2}{|c|}{ 沿岸; $\mathrm{A}_{\mathrm{x}}=0.03$, 岸沖 ; $\mathrm{A}_{\mathrm{z}}=0.1 \mathrm{~A}_{\mathrm{x}}$} \\
\hline 境界条件 & \multicolumn{2}{|c|}{ 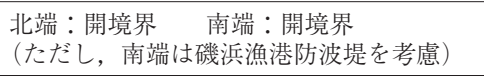 } \\
\hline 移動高 & \multicolumn{2}{|c|}{ T.P. $+2.0 \mathrm{~m}$ (陸側), T.P.-8.0m（沖側） } \\
\hline 交換層幅 & \multicolumn{2}{|l|}{$0.1 \mathrm{~m}$} \\
\hline 安息勾配 & \multicolumn{2}{|l|}{ 陸上：1/2, 水中： $1 / 3$} \\
\hline 計算時間間隔 & \multicolumn{2}{|l|}{$\Delta t=4 \mathrm{hr}$} \\
\hline 計算断面間隔 & \multicolumn{2}{|l|}{$\Delta x=50 \mathrm{~m}$} \\
\hline
\end{tabular}

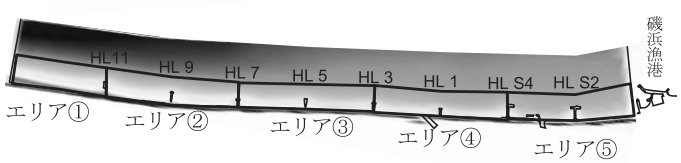

図-13 土量変化を評価するエリア区分図 


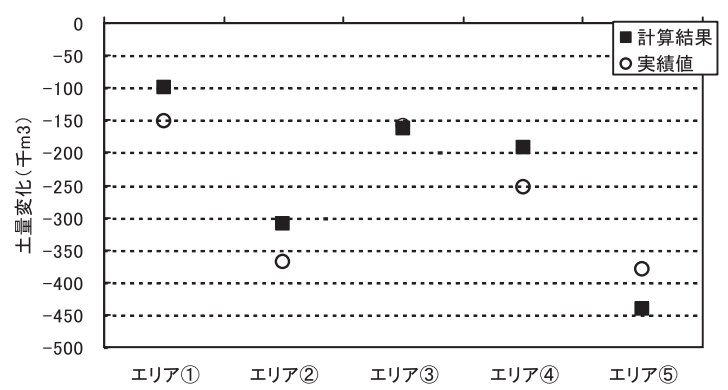

図-14 エリア毎の土量変化再現計算結果（1998～2008 年)

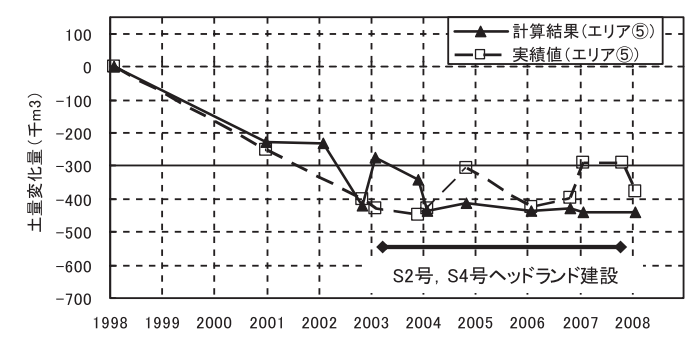

図-15 エリア(5)の土量経年変化の再現計算結果

ンドが建設されており，これらのへッドランドによる沿 岸漂砂の制御効果によるものと考えられる.

\section{5. 試験養浜の評価を踏まえた養浜計画と課題}

山元海岸は南からの土砂供給がほぼ期待できない上, 侵食が続き被災の危険性が高い状況にあることから，早 急な保全対策が必要である。一方で侵食傾向が強く細砂 による養浜の効果が得られにくい海岸でもある。 そこで, 効率的に海浜を回復させるために, 粒径 $2 \mathrm{~mm}$ 以上の粗粒 材を含む養浜を行う計画を立案し, 構築した海浜変形モ デルによって粒径の異なる養浜の効果について評価した.

養浜砂を粗粒材 $(2 \mathrm{~mm})$ もしくは採取土砂 $(0.25 \mathrm{~mm})$ とした場合の 2 ケースの予測計算を行った。各々，年間 5 万 $\mathrm{m}^{3}$ を投入し続けた場合の 10 年後までの等深線予測計 算結果を図-16に示す，図より，粗粒材を投入した場合 は水深 $1 \mathrm{~m}$ 等深線が 10 年後に $30 \mathrm{~m}$ に到達するが, 採取土 砂の場合は $10 \mathrm{~m}$ 程度と, 粗粒材養浜による効果が大きい ことがわかる.

粗粒材養浜による効果は, 石井ら（2006）によって, 茨城県神向寺海岸の例で得られている. 一方で, 生態等 の環境への影響が懸念されることから，粗粒材と同一漂 砂系内の採取土砂の両者を組み合わせた養浜を行ってい くことが重要と考えられる。土砂の確保のためには沿岸 域を含む各関係機関との連携を図ることが重要となる。

また，養浜事業を継続するためには効果を定量的に評 価し, 地域住民や漁業者等への説明責任を果たすことが 重要となるが, 養浜は定量的な効果が得られにくい事業

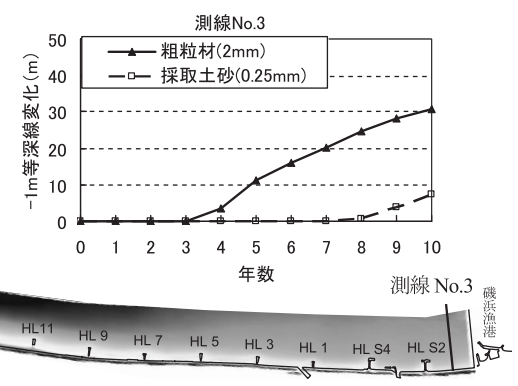

図-16 粒径の異なる養浜毎の水深 $1 \mathrm{~m}$ の等深線変化

でもあるため，簡易的に実施でき定量評価が可能な効果 的なモニタリング手法の開発が今後の課題である.

\section{6. とめ}

以下に，本研究より得られた知見をまとめる.

1）有義波高が $2 \mathrm{~m}$ 程度以上の波浪来襲時には， $0.3 \mathrm{~mm}$ 程 度の中砂もへッドランドを越えて移動する。

2）試験養浜によって投入した土砂は，投入完了 1 年後に 2 割の残存率となり, 約 8 割が投入地点から流出する結 果となった。

3）山元海岸は, 平衡海浜形状に対して凹型の侵食型の 海岸であるとともに，全体的な土砂流出が見られる.

4）中砂以上の砂の多くは, 水深 $2 \mathrm{~m}$ 以浅の汀線際に移動 し，1年後もある程度留まっていると推測される。

5）粗粒材を含む養浜を行うことで養浜の効率化が図れ, 環境への影響を十分に考慮した上で実施することが望 まれる。

謝辞：本研究で使用したデー夕は, 国土交通省東北地方 整備局仙台河川国道事務所から提供して頂きました。ま た，海浜変形モデルを構築するにあたって，東北大学災 害制御研究センターの真野明教授にご助言を頂きまし た。ここに謝意を申し上げます。

\section{参 考 文 献}

石井秀雄 - 中村友和 - 宇多高明 - 高橋 功 - 大木康弘 - 熊田 貴之（2006）：粗粒材養浜による砂浜の安定化に関する 現地実験, 海岸工学論文集, 第 53巻, pp. 681-685.

熊田貴之・小林昭男（2003）：沿岸・岸沖漂砂による粒径分 級を考慮した等深線変化モデル, 海岸工学論文集, 第 50 巻, pp. 481-485.

堀川清司・砂村継夫・近藤浩右（1974）：波による二次元海 浜変形に関する実験的研究, 海岸工学論文集, 第 21 巻, pp. 193-199.

三浦佑輔 - 南 將人 · 有働恵子 ·真野 明 (2008) : 仙台湾 南部海岸におけるへッドランド周辺の土砂輸送解析, 海 岸工学論文集, 第55巻, pp. 571-575.

Bruun, P. (1954) : Coast Erosion and the Development of Beach Profiles, U.S. Army Corps of Engineers, Beach Erosion Board, Tech. No.44. 